\title{
Ferric Reducing, Anti-radical and Cytotoxic Activities of Tinospora cordifolia Stem Extracts
}

Amit Kumar Sharma, Shashank Kumar and Abhay K. Pandey*

Department of Biochemistry, University of Allahabad, India

*Corresponding author: Pandey AK, Department of Biochemistry, University of Allahabad, Allahabad - 211002, India, Tel: +91 9839521138; E-mail: akpandey23@rediffmail.com

Received date: April 22, 2014, Accepted date: September 22, 2014, Published date: September 29, 2014

Copyright: ( 2014 Sharma AK, et al. This is an open-access article distributed under the terms of the Creative Commons Attribution License, which permits unrestricted use, distribution, and reproduction in any medium, provided the original author and source are credited.

\begin{abstract}
Introduction: Tinospora cordifolia (Menispermaceae) is used as folk remedy against many diseases. This work reports the antioxidant and cytotoxic activities of $T$. cordifolia stem extracts.

Materials and Methods: Dried samples were sequentially extracted in different solvents. Antioxidant activity was determined by using ferric reducing antioxidant power (FRAP), $\beta$-carotene bleaching and lipid peroxidation inhibition assays. Cytotoxicity against cancer cell lines was determined by SRB assay.

Results: Chloroform, ethyl acetate, acetone, and ethyl alcohol extracts demonstrated higher FRAP values (4981-6568 $\mu \mathrm{mol}$ ferrous sulphate equivalent/mg). Aqueous, ethyl alcohol and chloroform extracts showed better $\beta$ carotene bleaching inhibition potential (zone of inhibition $15 \mathrm{~mm}$ ). Acetone and ethyl alcohol extracts accounted for moderate $(48 \%$ and $53 \%$, respectively) lipid peroxidation inhibition in rat liver homogenate. Aqueous fraction of stem exhibited potent cytotoxic activity (67-99\%) against prostate, lung and colon cancer cell lines.
\end{abstract}

Conclusion: The study showed that $T$. cordifolia stem has considerable potential as antioxidant and cytotoxic agents.

Keywords: Antioxidant; FRAP; $\beta$-Carotene bleaching; Lipid peroxidation; Cell lines; Cytotoxicity; Tinospora cordifolia

\section{Introduction}

Active oxygen and free radicals, such as superoxide anion, hydrogen peroxide and hydroxyl radical, are formed in the body by normal metabolic action. Overload of these radicals are minimized by a balanced system of antioxidant defenses which include antioxidant compounds and enzymes [1,2]. Imbalance between antioxidant defense and reactive species causes oxidative stress, a pathophysiological condition, leading to many human diseases including cancer, aging and atherosclerosis [3]. Free radical causes peroxidation of unsaturated membrane lipids and disrupts their integrity which results into impaired functioning of cell. Lipid peroxidation is attracting much attention due to its involvement in physiological and pathological conditions of liver, kidney and brain toxicity. Antioxidants have capability to scavenge free radicals and thereby inhibit the lipid peroxidation $[4,5]$.

Literature revealed that antioxidant rich diet plays an essential role in the prevention of cardiovascular, neurodegenerative diseases and cancers. Currently there has been an increased interest globally to identify antioxidant compounds that are pharmacologically potent having low or no side effects [6]. Traditional herbal medicines form an important part of the healthcare system in India as they provide potential leads to find active and therapeutically useful compounds. Cancer is uncontrolled and unceasing proliferation of cells. This is the major cause of death (about 13\%) in humans. Plants are the potential source of chemical constituents with anticancer activities as they possess a variety of structurally diverse bioactive compounds $[7,8]$. They either have direct cytotoxic effect on cancer cells or affect processes involved in tumor development. Cancer chemotherapy has adverse effect on patients, thus there is a need to explore new anticancer drugs of herbal origin [9].

Tinospora cordifolia (Menispermaceae) is an indigenous plant commonly known as amrita, guduchi, shindilkodi, giloy and gulancha etc. It is a large spreading, glabrous, perennial, deciduous, climbing shrub distributed throughout India as well as in China, Burma and Sri Lanka. The plant is used in Ayurveda, Unani and Chinese systems of medicine $[9,10]$. Arabinogalactan a polysaccharide present in the plant is known to produce immunological activity. T. cordifolia has also been shown to possess activity against many pathophysiological conditions $[9,10]$. Present communication reports the antioxidant and cytotoxic activities of $T$. cordifolia stem extracts.

\section{Materials and Methods}

\section{Plant material and extract preparation}

T. cordifolia stem was collected in summer 2012 from Science Faculty Campus, University of Allahabad and authenticated by experts in the Botany Department, University of Allahabad, Allahabad, India. Shade dried stem was crushed and ground into fine powder with mortar and pestle. Powdered sample was sequentially extracted with hexane (HX), benzene (BZ), chloroform $(\mathrm{CH})$, ethyl acetate (EA), acetone (AC),ethyl alcohol (ET) and water (AQ) in Soxhlet apparatus for $8 \mathrm{~h}[11,12]$. The extracts were lyophilized and dissolved in DMSO or in respective solvents for determination of biochemical activities. 
Page 2 of 5

\section{Total antioxidant activity determination by FRAP assay}

Ferric reducing antioxidant power (FRAP) assay was used to determine total antioxidant potential of extracts [13]. FRAP reagent was freshly prepared by mixing $25 \mathrm{ml}$ acetate buffer ( $300 \mathrm{mM}, \mathrm{pH} 3.6)$, $2.5 \mathrm{ml} \mathrm{TPTZ}$ solution $(10 \mathrm{mM}$ TPTZ in $40 \mathrm{mmol} / \mathrm{l} \mathrm{HCl})$ and $2.5 \mathrm{ml}$ $\mathrm{FeCl}_{3}(20 \mathrm{mM})$ water solution. One and half $\mathrm{ml}$ of each sample (1 $\mathrm{mg} / \mathrm{ml}$ ) dissolved in methanol was added in $4.5 \mathrm{ml}$ of FRAP reagent, stirred and after $5 \mathrm{~min}$ absorbance was measured at $593 \mathrm{~nm}$, using FRAP working solution as blank. Calibration curve of ferrous sulfate $(100-1000 \mu \mathrm{mol} / \mathrm{l})$ was used, and results were expressed in $\mu \mathrm{mol}$ $\mathrm{Fe}^{2+} / \mathrm{mg}$ dry weight of extract.

\section{$\beta$-Carotene bleaching assay}

The antioxidant activities of $T$. cordifolia extracts were investigated according to the method of Dorman et al. [14]. Two gram of agar was completely dissolved in $100 \mathrm{ml}$ hot water and the solution was allowed to cool up to $50^{\circ} \mathrm{C}$ followed by addition of $4 \mathrm{ml}$ linoleic acid $(5 \mathrm{mg} / \mathrm{ml}$ in ethanol) and $20 \mathrm{ml} \beta$-carotene ( $1 \mathrm{mg} / \mathrm{ml}$ in acetone). The agar was poured into Petri dishes and allowed to set for $30 \mathrm{~min}$. Wells $(4 \mathrm{~mm}$ diameter) were punched into the agar of each Petri dish using a sterile cork borer. Plant extracts $(30 \mu \mathrm{l})$ prepared in DMSO $(2 \mathrm{mg} / \mathrm{ml})$ was added to each well. BHT was used as standard. Plates were incubated overnight at $45^{\circ} \mathrm{C}$ until the background colour had bleached. The experiment was performed in triplicate and results were shown as average.

\section{Lipid Peroxidation Inhibition (LPOI) Assay}

The lipo-protective efficacy of extract was estimated by the method of Halliwell and Gutteridge [4] using some modification [15]. The liver tissue was isolated from normal albino Wistar rats and $10 \%(\mathrm{w} / \mathrm{v})$ homogenate was prepared in phosphate buffer $(0.1 \mathrm{M}, \mathrm{pH} 7.4$ having $0.15 \mathrm{M} \mathrm{KCl}$ ) using homogenizer at $40^{\circ} \mathrm{C}$. The homogenate was centrifuged at $800 \mathrm{~g}$ for $15 \mathrm{~min}$ and clear cell free supernatant was used for in vitro lipid per-oxidation inhibition assay. One hundred microlitre of extract $(2 \mathrm{mg} / \mathrm{ml})$ dissolved in respective solvents was evaporated to dryness followed by addition of $1 \mathrm{ml} \mathrm{KCl}(0.15 \mathrm{M})$ and $0.5 \mathrm{ml}$ of tissue homogenate. Peroxidation was initiated by adding 100 $\mu \mathrm{l} \mathrm{FeCl}_{3}(0.2 \mathrm{mM})$. After incubation at $37^{\circ} \mathrm{C}$ for $30 \mathrm{~min}$, lipid peroxidation was monitored by the formation of thiobarbituric acid reactive substances which were estimated by adding $2 \mathrm{ml}$ of ice-cold hydrochloric acid $(0.25 \mathrm{~N})$ containing $15 \%$ TCA, $0.38 \%$ TBA and $0.5 \%$ BHT. The reaction mixture was incubated at $80^{\circ} \mathrm{C}$ for $1 \mathrm{~h}$ followed by cooling and centrifugation. The absorbance of the pink supernatant was measured at $532 \mathrm{~nm}$. BHA was used as standard for comparison. All analyses were carried out in triplicate and results were expressed as mean \pm SD. The protective effect of extracts against lipid peroxidation (\% LPOI) was calculated by using the following formula:

$$
\% \text { LPOI }=[(\mathrm{A} 0-\mathrm{A} 1) / \mathrm{A} 0] \times 100
$$

Where $\mathrm{A} 0$ is the absorbance of control and $\mathrm{Al}$ is absorbance in the presence of the sample/standard compounds. The results were expressed as mean \pm SD of three replicates.

\section{Cell lines, growth conditions and treatment}

Human cancer cell lines namely Colon (Colo-205; HCT-116), prostrate (PC-3), lungs (A-549; NCI-H322), and breast (T-47D) were procured from National Center for Cell Sciences, Pune, India. Cell lines were grown and maintained in RPMI-1640 medium, $\mathrm{pH} 7.4$ with
$10 \%$ FCS, 100 units $/ \mathrm{ml}$ penicillin, $100 \mu \mathrm{g} / \mathrm{ml}$ streptomycin and $2 \mathrm{mM}$ glutamine. Cells were grown in $\mathrm{CO}_{2}$ incubator (Heraeus, $\mathrm{GmbH}$ Germany) at $37^{\circ} \mathrm{C}$ in the presence of $90 \%$ humidity and $5 \% \mathrm{CO}_{2}$.

\section{Cytotoxic assay by sulforhodamine B dye method}

The in vitro cytotoxicity of extract was determined using sulforhodamine-B dye (SRB) assay [16]. Cell suspension $\left(100 \mu \mathrm{l}, 1 \times 10^{5}\right.$ to $2 \times 10^{5}$ cells per $\mathrm{ml}$ depending upon mass doubling time of cells) was grown in 96-well tissue culture plate and incubated for 24 hours. Stock solutions of test extracts were prepared in DMSO and serially diluted with growth medium to obtain desired concentrations. $100 \mu \mathrm{l}$ test extract $(100 \mu \mathrm{g} /$ well $)$ was then added to the wells and cells were further incubated for another $48 \mathrm{~h}$. The cell growth was arrested by layering 50 $\mu \mathrm{l}$ of $50 \%$ TCA and incubated at $40^{\circ} \mathrm{C}$ for an hour followed by washing with distilled water and then air-dried. SRB $(100 \mu \mathrm{l}, 0.4 \%$ in $1 \%$ acetic acid) was added to each well and plates were incubated at room temperature for $30 \mathrm{~min}$. The unbound SRB dye was washed with $1 \%$ acetic acid and then plates were air dried. Tris- $\mathrm{HCl}$ buffer $(100 \mu \mathrm{l}, 0.01$ $\mathrm{M}, \mathrm{pH}$ 10.4) was added and the absorbance was recorded on ELISA reader at $540 \mathrm{~nm}$. Each test was done in triplicate. The values are reported as mean $\pm \mathrm{SD}$ of three replicates.

\section{Statistical Analysis}

All experiments were carried out in triplicate and data were expressed as mean \pm standard deviation (SD) or standard error of mean (SEM). The plots were prepared using GraphPad Prism software. Data were analyzed using one way ANOVA and the values of $\mathrm{p}<0.05$ were considered as statistically significant.

\section{Results}

\section{Ferric reducing antioxidant power}

Ferric reducing capability of the extracts was done by using FRAP assay. AC extract demonstrated considerable reducing ability (6568.88 $\pm 0.05 \mu \mathrm{mol} \mathrm{FeSO}_{4} .7 \mathrm{H}_{2} \mathrm{O}$ equivalent $/ \mathrm{mg}$ ) followed by $\mathrm{CH}$, ET and $\mathrm{EA}$ fractions (Table 1). Rest of the extracts showed low reducing ability in the range of $1516-2691 \mu \mathrm{mol} \mathrm{FeSO}{ }_{4} \cdot 7 \mathrm{H}_{2} \mathrm{O}$ equivalent/mg sample.

\begin{tabular}{|l|l|l|}
\hline Extract & FRAP value & $\begin{array}{l}\beta \text {-carotene } \\
\text { inhibition }(\mathbf{m m})\end{array}$ \\
\hline $\mathrm{HX}$ & $1516.90 \pm 0.03$ & 10 \\
\hline $\mathrm{BZ}$ & $1625.02 \pm 0.01$ & 10 \\
\hline $\mathrm{CH}$ & $5659.72 \pm 0.02$ & 15 \\
\hline $\mathrm{EA}$ & $4981.53 \pm 0.01$ & 10 \\
\hline $\mathrm{AC}$ & $6568.88 \pm 0.05$ & 10 \\
\hline $\mathrm{ET}$ & $5300.97 \pm 0.01$ & 15 \\
\hline $\mathrm{AQ}$ & $2691.73 \pm 0.02$ & 15 \\
\hline
\end{tabular}

Table 1: FRAP value and $\beta$-carotene bleaching inhibition activity of $T$. cordifolia stem extracts. Abbreviations: HX-hexane, B-benzene, $\mathrm{CH}$ chloroform, EA-ethyl acetate, AC-acetone, ET-ethyl alcohol, AQaqueous, FRAP-ferric reducing antioxidant power. FRAP values are expressed as $\mu \mathrm{mol} \mathrm{FeSO}_{4} .7 \mathrm{H} 2 \mathrm{O}$ equivalent $/ \mathrm{mg}$ sample (mean $\pm \mathrm{SEM}$, $\mathrm{n}=3, \mathrm{p}<0.05)$. 


\section{Beta-carotene bleaching inhibition activity}

Antioxidant activity of the extracts was assayed by $\beta$-carotene bleaching well agar diffusion method and results are depicted in Table 1. Some of the extracts $(\mathrm{CH}, \mathrm{ET}$ and $\mathrm{AQ})$ showed appreciable antioxidant potential (ZOI-15 $\mathrm{mm}$ ) as compared with standard compound BHT (ZOI-15 mm). Rest of the extracts showed low activity (ZOI-10 $\mathrm{mm})$.

\section{Lipid peroxidation inhibition assay}

Lipoprotective activity of the extracts $(2 \mathrm{mg} / \mathrm{ml})$ derived from $T$. cordifolia stem showed moderate protection (38-53\%) against lipid peroxidation in rat liver homogenate (Figure 1).

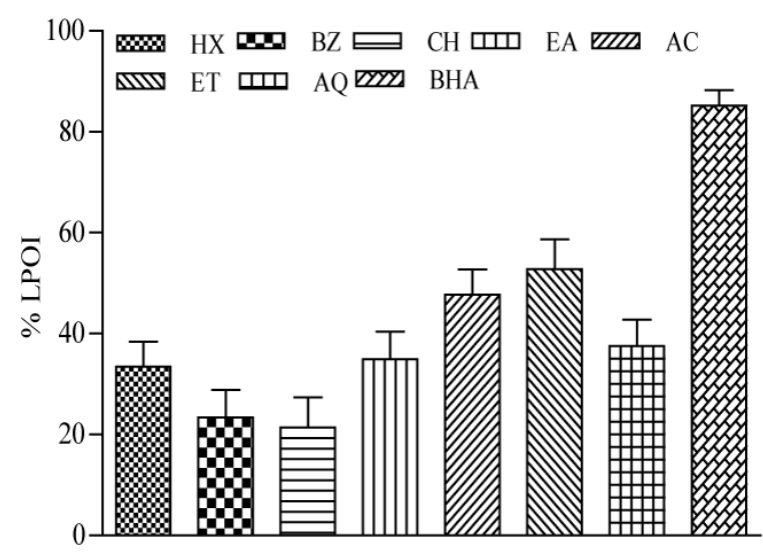

Figure 1: Lipid peroxidation inhibition activity of $T$. cordifolia stem extracts. Phytochemicals present in sample were extracted with HX (hexane), BZ (benzene), $\mathrm{CH}$ (chloroform), EA (ethyl acetate), AC (acetone), ET (ethyl alcohol) and AQ (water) as described in materials and methods section. Lipid peroxidation inhibition (\%LPOI) activity was determined in presence of $200 \mu \mathrm{g}$ of extract in reaction mixture and BHA was used as standard. Absorbance was recorded at $532 \mathrm{~nm}$. The results are expressed as mean $\pm \mathrm{SD}(\mathrm{n}=3, \mathrm{p}$ $<0.05)$.

Among all the fractions ET extract showed maximum (53\%) lipid peroxidation inhibition activity at test concentration. Most of the fractions exhibited about $21-34 \%$ inhibition activity. BHA accounted for about $85 \%$ protection against lipid peroxidation at same concentration.

\section{Anticancer activity}

The cytotoxic activity of $T$. cordifolia stem polar (AQ) and nonpolar (HX) fractions was tested against six cancer cell lines viz., prostate (PC-3), colon (Colo-205, HCT-116), lung (A549, NCI-H322) and breast cancer (T47D) in presence of $100 \mu$ g extract per well using SRB assay and results are shown in Figure 2. AQ fraction showed appreciable cytotoxic activity (67-99\%) against most of the cell lines. HX fraction produced moderate (62\%) cytotoxic activity against lung cancer cell line (A549). Standard anticancer drugs exhibited 50-98\% cytotoxicity against different test cell lines.

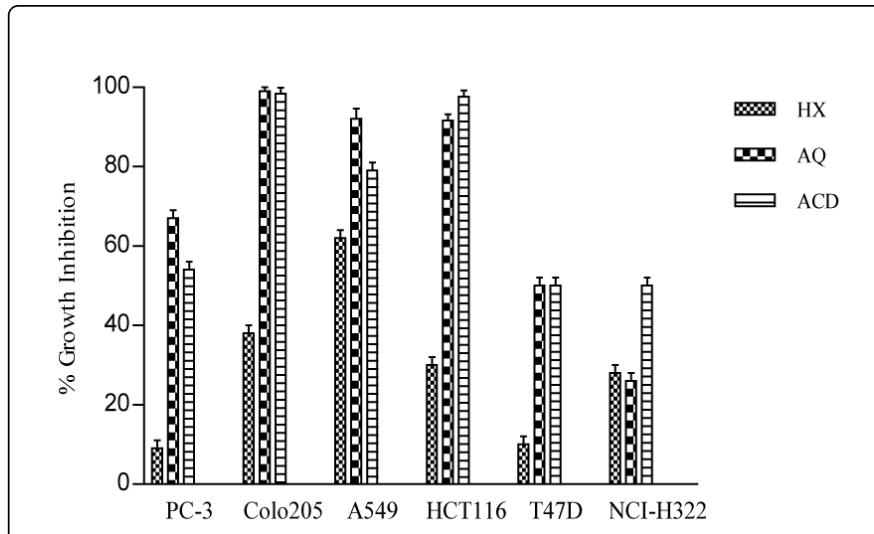

Figure 2: Cytotoxic effect of $T$. cordifolia stem extracts against cancer cell lines by SRB assay. Percentage growth inhibition of cell lines was assayed in presence of $100 \mu \mathrm{g}$ of extract per well against prostate (PC-3), colon (Colo-205, HCT-116), lung (A549, NCI$\mathrm{H} 322$ ) and breast cancer (T47D) cell line as described in materials and methods section. Abbreviations: HX-hexane, AQ-water, ACDanti cancer drugs [mitomycin $\mathrm{C}(10 \mu \mathrm{M})$ against PC-3 and T47D; paclitaxel $(10 \mu \mathrm{M})$ against Colo205, A549 and HCT116; 5fluorouracil $(20 \mu \mathrm{M})$ against NCI-H322]. Data represent mean \pm $\operatorname{SD}(\mathrm{n}=3, \mathrm{p}<0.05)$.

\section{Discussion}

FRAP assay uses a complex of ferric ion and tripyridyltriazine (TPTZ) as reagents to assess the reducing ability of compounds. The FRAP assay relies upon the reduction from the ferric ion-TPTZ complex to the ferrous ion-TPTZ complex by antioxidants which can be measured at $593 \mathrm{~nm}[13,17]$. This gives a direct measurement of antioxidant capacity of samples. Result demonstrated that most of the stem extracts $(\mathrm{CH}, \mathrm{EA}, \mathrm{AC}$ and $\mathrm{ET})$ had higher FRAP values indicating the antioxidant capability of the phytoconstituents present in $T$. cordifolia stem (Table 1).

Chromophores such as $\beta$-carotene have alternate double and single carbon-carbon bonds which are known as conjugated system. The electrons in the $\pi$-orbitals of the double bonds overlap, creating a system of delocalized electrons across a large part of the molecule. Carotenoids undergo bleaching (loss of color) when exposed to radicals or to oxidizing species which involves interruption of the conjugated double bond system either by cleavage or by addition to one of the double bonds $[18,19]$. The results demonstrated that some of the extracts $(\mathrm{CH}, \mathrm{ET}$ and $\mathrm{AQ})$ possess appreciable $\beta$-carotene bleaching inhibition activity (ZOI $15 \mathrm{~mm}$, Table 1 ). This indicates that T. cordifolia stem extracts exhibit antioxidant potential by virtue of their radical scavenging activity. Polyphenolic contents of the extracts have been reported to function as good electron and hydrogen atom donors and therefore should be able to terminate radical chain reaction by converting free radicals and ROS to more stable products $[9,18]$. Higher FRAP value and appreciable bleaching inhibition effect observed in $T$. cordifolia extracts could also be attributed to the total phenolic contents.

In mammals lipid peroxidation is related to injury and inflammation and is often due to the oxidative deterioration of the cellular membrane lipids [2]. Peroxidation of lipids in the body may be 
enzymatic and non-enzymatic or both. Non enzymatic reaction involves initiation, propagation and termination phases [1]. Lipid, lipoperoxyl, lipid hydroperoxide, peroxyl and alcoxyl radicals produced in the first two phases of lipid peroxidation are deleterious for the body. Malondialdehyde (MDA) an important byproduct of lipid peroxidation react with thiobarbituric acid (TBA) to form TBAMDA adduct with an absorbance maximum at $532 \mathrm{~nm}$ [20]. In present study ET fraction of the $T$. cordifolia stem led to reduction of adduct formation in LPOI assay indicating its lipoprotective potential (Figure 1). Other studies have also revealed the protective effect of medicinal plants against membrane damage which are in agreement with our reports $[21,22]$. This activity could be attributed to the antioxidant potential of phytochemicals present in the extract $[5,19,23]$.

Plant derived compounds such as vinblastine; camptothecin and paclitaxel have been used as anticancer agents. Plant extracts have been shown to fragment DNA, arrest cell cycle, decrease mitochondrial membrane potential and ultimately induce apoptosis in various cancer cell lines [24-26]. The study revealed that AQ extract of T. cordifolia stem possesses noticeable activity (67-99\%) against lung and colon cancer cell lines. The activity was comparable with the activity of standard anticancer drugs (Figure 2). Earlier studies have also shown the cytotoxic effect of $T$. cordifolia against other cancer cell lines [9]. Differential cytotoxic activity in the extracts might be due to differential distribution of phytoconstituents in various fractions during the sequential extraction of extracts. Moreover differential behavior of cell lines might also be attributed to different molecular characteristics of the test cell lines [9]. Phytochemicals viz. phenolics, flavonoids, cardiac glycosides, alkaloids, and saponins are reported to be present in aqueous $T$. cordifolia stem extracts which may be responsible for the cytotoxic activity [3,9]. The potent cytotoxic activity in the aqueous extract indicates its potential for development of future anticancer agents.

\section{Conclusion}

The study revealed that the phytochemicals present in various $T$. cordifolia stem extracts have capability to counteract the damaging effect of free radicals because of its antioxidant properties i.e., reducing ability, radical scavenging, and lipo-protective activities. The aqueous extract exhibited considerable cytotoxic activity against lung and colon cancer cell lines. Thus study provides insight to researchers for future utilization of this plant for pharmaceutical purposes.

\section{Acknowledgement}

AKS acknowledges financial support from University of Allahabad, Allahabad, India in the form of UGC-CRET research fellowships. SK also acknowledges financial support from UGC, India in the form of Rajiv Gandhi National Senior Research Fellowship.

\section{References}

1. Guéraud F, Atalay M, Bresgen N, Cipak A, Eckl PM, et al. (2010) Chemistry and biochemistry of lipid peroxidation products. Free Radic Res 44: 1098-1124.

2. Kumar S, Pandey AK (2014) Medicinal attributes of Solanum xanthocarpum fruit consumed by several tribal communities as food: an in vitro antioxidant, anticancer and anti HIV perspective. BMC Complement Altern Med 14: 112.

3. Mishra A, Kumar S, Bhargava A, Sharma B, Pandey AK (2011) Studies on in vitro antioxidant and antistaphylococcal activities of some important medicinal plants. Cell Mol Biol 57: 16-25.
4. Halliwell B, Gutteridge JNC (1999) Mechanism of damage of cellular targets by oxidative stress: lipid peroxidation, In Free Radicals in Biology and Medicine (Halliwell B and Gutteridge JMC Ed.), Oxford University Press UK: Oxford, 284-313.

5. Kumar S, Gupta A, Pandey AK (2013) Calotropis procera root extract has the capability to combat free radical mediated damage. ISRN Pharmacol 2013: 691372.

6. Pandey AK, Mishra AK, Mishra A (2012) Antifungal and antioxidative potential of oil and extracts derived from leaves of Indian spice plant Cinnamomum tamala. Cell Mol Biol 58: 142-147.

7. Indap MA, Radhika S, Motiwale L, Rao KVK (2006) Quercetin: antitumor activity and pharmacological manifestations for increased therapeutic gains. Indian J Pharm Sci 68: 465- 469.

8. Kim JB, Koo HN, Joeng HJ, Lyu YS, Park SG, et al. (2005) Induction of apoptosis by Korean medicine Gagam-whanglyun-haedoktang through activation of caspase-3 in human leukemia cell line, HL-60 cells. J Pharmacol Sci 97: 138-145.

9. Mishra A, Kumar S, Pandey AK (2013) Scientific validation of the medicinal efficacy of Tinospora cordifolia. ScientificWorldJournal 2013: 292934.

10. Singh S, Pandey S, Srivastava S, Gupta V, Patro B, et al. (2003) Chemistry and medicinal properties of Tinospora cordifolia (Guduchi). Ind J Pharmacol 35: 83-91.

11. Mishra AK, Mishra A, Kehri HK, Sharma B, Pandey AK(2009) Inhibitory activity of Indian spice plant Cinnamomum zeylanicum extracts against Alternaria solani and Curvuluria lunata, the pathogenic dematiaceous moulds. Ann Clin Microbiol Antimicrobials 8: 9.

12. Pandey AK (2007) Anti-staphylococcal activity of a pan-tropical aggressive and obnoxious weed Parthenium hysterophorus: an in vitro study. Natl Acad Sci Lett 30: 383-386.

13. Benzie IF, Strain JJ (1996) The ferric reducing ability of plasma (FRAP) as a measure of "antioxidant power": the FRAP assay. Anal Biochem 239: 70-76.

14. Dorman HJD, Figueiredo AC, Barroso JG, Dean SG (2000) In vitro evaluation of antioxidant activity of essential oils and their components. Flavour Frag J 15: 12-16.

15. Kumar S, Pandey AK (2012) Antioxidant, lipo-protective and antibacterial activities of phytoconstituents present in Solanum xanthocarpum root. Int Rev Biophysical Chem 3: 42-47.

16. Skehan P, Storeng R, Scudiero D, Monks A, McMahon J, et al. (1990) New colorimetric cytotoxicity assay for anticancer-drug screening. J Natl Cancer Inst 82: 1107-1112.

17. Luximon-Ramma A, Bahorun T, Soobrattee MA, Aruoma OI (2002) Antioxidant activities of phenolic, proanthocyanidin, and flavonoid components in extracts of Cassia fistula. J Agric Food Chem 50: 5042-5047.

18. Kumar S, Pandey S, Pandey AK (2014) In vitro antibacterial, antioxidant, and cytotoxic activities of Parthenium hysterophorus and characterization of extracts by LC-MS analysis. Biomed Res Int 2014: 495154.

19. Huang D, Ou B, Prior RL (2005) The chemistry behind antioxidant capacity assays. J Agric Food Chem 53: 1841-1856.

20. Kumar S, Mishra A, Pandey AK (2013) Antioxidant mediated protective effect of Parthenium hysterophorus against oxidative damage using in vitro models. BMC Complement Altern Med 13: 120.

21. Kumar S, Pandey AK (2012) Phenolic content, reducing power and membrane protective activities of Solanum xanthocarpum root extracts. Vegetos 26: 301-307.

22. Kumar S, Sharma UK, Sharma AK, Pandey AK (2012) Protective efficacy of Solanum xanthocarpum root extracts against free radical damage: phytochemical analysis and antioxidant effect. Cell Mol Biol (Noisy-legrand) 58: 174-181.

23. Khan RA, Khan MR, Ahmed M, Sahreen S, Shah NA, et al. (2012) Hepatoprotection with a chloroform extract of Launaea procumbens 
Citation: Sharma AK, Kumar S, Pandey AK (2014) Ferric Reducing, Anti-radical and Cytotoxic Activities of Tinospora cordifolia Stem Extracts. Biochem Anal Biochem 3: 153. doi:10.4172/2161-1009.1000153

Page 5 of 5

against CCl4-induced injuries in rats. BMC Complement Altern Med 12 114.

24. Mishra A, Sharma AK, Kumar S, Saxena AK, Pandey AK (2013) Bauhinia variegata leaf extracts exhibit considerable antibacterial, antioxidant, and anticancer activities. Biomed Res Int 2013: 915436.

25. Mollah ML, Song JC, Park CH, Lee GD, Hong JH, et al. (2009) Anticancer activity and apoptotic effects of Bulnesia sarmienti against human lung cancer H460 cells. Oncol Res 18: 259-267.
26. Kumar S, Chashoo G, Saxena AK, Pandey AK (2013) Parthenium hysterophorus. a probable source of anticancer, antioxidant and antiHIV agents. Biomed Res Int 2013: 810734. 